\title{
whither the Absiracts-a crisis
}

\author{
(A Presidential message to the members of the American Meteorological \\ Society)
}

Although now in its nineteenth year of continuous publication, and ranked as one of the world's most outstanding abstracting services and journals, the Society's MeteoroLOGICAL and GEOASTROPHYSiCAL ABSTRACTs has been frequently plagued by financial difficulties. Throughout its history the MGA, and its predecessor, Meteorological ABstracts, has depended upon funds from federal agencies to cover the difference between the costs of publication and the income derived from subscriptions. Despite all efforts on the part of the officers of the Society, such as drastic increases in subscription rates, and directed sales campaigns, it has not been possible to eliminate this deficit and make the MGA a self-sustaining publication.

In 1967 a detailed study of the operations and costs of MGA was undertaken in order to identify means for reducing the costs of MGA, hopefully without impairing its quality and coverage, but, if this were necessary, we also wished to identify the minimum changes required to achieve financial sufficiency for this journal. This study indicated very clearly that no substantial savings in costs are possible without drastic changes in the quality of the MGA. In particular, the present informative abstracts would have to be replaced by largely indicative abstracts if substantial reduction in costs are to be achieved.

The 1967 MGA operations analysis also noted that the financial position of the MGA could be much improved if its preparation was largely converted to computer-based methods, and the study outlined the steps necessary to achieve this goal. Not only could costs for publication of the journal be improved, but the preparation of other information outputs, such as title listings, selective bibliographies, and the like, could be done with only slight increases in costs. These peripheral or secondary products could provide substantial additional income to the MGA operation. Such a change in operations will require several years time and investment in equipment and computer programs.

At the present time the Society is undertaking a second study of the user requirements for the abstracts and secondary products. This is a natural companion of the operations study, since it is evident the demand for these services will set the limit on income which can be produced. Many of you will be contacted with regard to your own uses of the MGA and for your suggestions regarding ways it, or other services, could be made more useful to you. I hope you will give these requests your most considered attention.

During 1968 your Society must make several far reaching decisions with regard to the future of the MGA. The studies mentioned above will provide us with the information which we will need for these decisions. But, more importantly, the response to the subscription campaign for the 1969 volume of MGA will dictate whether or not this publication is continued and, if it is, in what form. We now know that for 1969 the MGA must be essentially self-supporting, and this means an increase of about $\$ 100,000$ in subscriptions over the 1968 level of $\$ 150,000$. In order to meet this goal, an intensive subscription campaign will be undertaken between now and September and subscribers will be asked to submit their subscription orders before October 1 . The decision with regard to the future of MGA will then depend upon the success of this campaign.

The Meteorological and Geoastrophysical Abstracts have provided a highly useful condensation of the world's technical literature in our professional areas of interest. I am sure you share my concern that this very important service be continued under the guidance of our Society. You can help assure this by letting the Society know of your own needs for this service, and by your personal efforts to place subscriptions for this journal in the libraries, research laboratories, and meteorological work shops about you as well as in your own professional library. 


\section{SELECTED LIST OF SERIAL PUBLICATIONS MOST FREQUENTLY CITED IN METEOROLOGICAL AND GEOASTROPHYSICAL ABSTRACTS}

These serial publications regularly contain an abundance of material on meteorology and geoastrophysics. The form used in $M G A$ is given below.

Acta Climatologica, Szeged, Hungary

Acta Geophysica Polonica, Warsaw

Acta Meteorologica Sinica, Peking

Advances in Geophysics, N. Y.

Advances in Space Science and Technology, N. Y.

Agricultural Meteorology, Amsterdam

Akademiia Nauk SSSR, Doklady, Ser. Matematika, Fizika

Akademiia Nauk SSSR. Izvestiia. Fizika Atmosfery i Okeana

Akademiia Nauk SSSR. Izvestiia. Fizika Zemli

Akademiia Nauk SSSR. Izvestiia. Ser, Geogr.

Akademiia Nauk SSSR. Izvestiya. Atmospheric and Oceanic Physics

Akademiia Nauk SSSR. Institut Okeanologii, Trudy

Akademiia Nauk SSSR. Mezhduvedomstvennyĭ Geofizicheskii Komitet, Rezul'taty Issledovanii Do Programme MGG [Various series]

Akademiia Nauk Ukrainskol RSR. Morskoĭ Gidrofizicheskil Institut, Trudy

American Geophysical Union, Geophysical Monographs

American Geophysical Union, Transactions

American Meteorological Society, Bulletin

Angewandte Meteorologie, Berlin

Annales d'Astrophysique, Paris

Annales de Géophysique, Paris

Annali di Geofisica, Rome

Archiv für Meteorologie, Geophysik und Bioklimatologie, Ser. A [and] Ser. B, Vienna

tologie, Ser. A [and] Ser. B,
Arkiv för Geof ysik, Stockholm

Astronomical Journal, New Haven, Conn.

Astronomicheskil Zhurnal, Moscow

Astronomicheskil Zhurnal, Moscon

Astrophysical Journal, Chicago

Australian Journal of Physics, Melbourne

Australian Meteorological Magazing

Beiträge zur Geophysik, Leipzig

Beiträge zur Physik der Atmosphäre, Frankfurt a.M. Izvestiia

Bulletin de Geophysique, Montreal

Bulletin de Geophysique, Montreal
Canada. Meteorological Branch, Circular

Canadian Journal of Physics, Ottawa

Ciel et Terre, Brussels

Dal'nevostochnyI Nauchno-Issledovatel'skil Gidrometeorologicheskil Institut, Vladivostok, Trudy

Deutsche Hydrographische Zeitschrift, Hamburg

France. Comité Central d'Océanographie et d'Etude des Côtes, Cahiers Océanographiques

France. Météorologie Nationale, Monographies

Geofisica et Meteorologia, Genoa

Geof ysiske Publikasjoner, Oslo

Geograficheskoe Obshchestvo SSSR, Izvestiia

Geomagnetism and Aeronomy, Wash., D. C.

Geomagnetizm i Aeronomiia, Moscow

Geophysica, Helsinki

Geophysical Journal, London

Geophysical Magazine, Tokyo

Germany (Federal Republic). Deutscher Wetterdienst. Berichte

Germany (Federal Republic). Deutscher Wetterdienst, Mitteilungen

Great Britain. Meteorological Office, Scientific Papers Hamburg. Seewetteramt, Einzelveröffentlichungen Helsinki. Universitet. Meteorologiska Institutet, Mit teilungen

Hidrotehnica, Gospodărirea Apelor, Meteorologia, Bucharest

Hungary. Országos Meteorológiai Intézet, Hivatalos Kiadványai

Idojárás, Budapest

Indian Journal of Meteorology and Geophysics, Delhi

International Journal of Biometeorology, Amsterdam

Japan. Science Council. Ionosphere Research Com-

mittee, Report of Ionosphere and Space Research in Japan
Journal de Mécanique et de Physique de l'Atmosphère Paris

Journal de Recherches Atmosphériques, Clermont.

Journal of Agricultural Meteorology, Tokyo

Journal of Applied Meteorology, Boston

Journal of Geomagnetism and Geoelectricity, Kyoto, Japan

Journal of Geophysical Research, Wash., D. C.

Journal of Glaciology, Cambridge, England

Journal of Hydrology, Amsterdam

Journal of Marine Research, New Haven

Journal of Meteorological Research, Tokyo

Journal of the Atmospheric Sciences, Boston

Khidrologiia i Meteorologiia, Sofia

Kiev. Ukraine. Nauchno-Issledovatel'skil Gidrometeorologicheskil Institut, Trudy

Kosmicheskie Issledovaniia, Moscow

Leningrad. Glavnaia Geofizicheskaia Observatoriia,

Trudy.
Leningrad. Gosudarstvennyi GidrologicheskiY Institut, Trudy

Leningrad. Nauchno-Issledovatel'skil Institut-Aeroklimatologii, Trudy

Limnology and Oceanography, Lawrence, Kan.

Marine Observer, London

Meteoritika, Moscov

Meteorological Magazine, London

Meteorological Monsen

Meteorological Society of Japan, Tokyo, Journa

Meteorologické Zprávy, Prague

Metéorologie, Paris

Meteorologiia i Gidrologiia, Moscow

Meteorologische Rundschau, Berlin

Monthly Weather Review, Wash., D. C.

Moscow. Gosudarstvennyi Okeanograficheskil Institut, Moscow. Gosudarstvennyl Okeanograficheskil Institut, Trudy

Moscow. Tsentral'naia Aerologicheskaia Observatoriia,

Moscow. Tsentral'nyi Institut Prognozov, Trudy

Nagoya. Univ. Research Institute of Átmospherics, Proceedings

Netherlands Journal of Sea Research, Den Helden

New Zealand Journal of Geology and Geophysics, Wellington

Oceanographical Society of Japan, Tokyo, Journal

Oceanography and Marine Biology, London

Okeanologiia, Moscow

Planetary and Space Science, Oxford

Problemy Arktiki i Antartiki, Leningrad

Progress in Oceanography, Oxford

Przegląd Geofizyczny, Warsaw

Pure and Applied Geophysics, Basel

Radio Science, Wash., D. C

Reviews of Geophysics, Wash., D. C.

Rivista di Meteorologia Aeronautica, Rome

Royal Meteorological Society, London, Quarterly Journal

Rumania. Institutul Meteorologic, Bucharest, Culegere de Lucrări

Sendai, Japan. Tohoku Univ., Science Reports, 5th Ser., Geophysics

Soviet Hydrology: Selected Papers, Wash. D. C. Space Science Reviews, Dordrecht, Holland

Sredneaziatskii Nauchno-Issledovatel'skii Gidrometeorologicheski Institut, Trudy

Studia Geophysica et Geodaetica, Prague

Tellus Stopholm

Tellus, Stockholm

Water Resources

Weather, London

Weatherwise, Boston

Wetter und Leben, Vienna

World Meteorological Organization, Technical Notes

Zeitschrift für Meteorologie, Berlin

Volume 19, 1968 Monthly plus Cumulative Annual Index

Government Agencies; Industrial, Commercial, Scientific and Research Organizations

Educational Institutions and Public Libraries

$\$ 200.00$ 